Abstracta Iranica Abstracta Iranica

Revue bibliographique pour le domaine irano-aryen

Volume 30 | 2010

Comptes rendus des publications de 2007

\title{
« The growing Corpus of Yehud Stamp Impressions: New Finds and New Research ». Tel Aviv, 34/1, 2007, $120 \mathrm{p}$.
}

\section{Astrid Nunn}

\section{(2) OpenEdition}

1 Journals

Édition électronique

URL : http://journals.openedition.org/abstractairanica/37665

DOI : 10.4000/abstractairanica.37665

ISSN : 1961-960X

Éditeur :

CNRS (UMR 7528 Mondes iraniens et indiens), Éditions de l'IFRI

Édition imprimée

Date de publication : 8 avril 2010

ISSN : 0240-8910

Référence électronique

Astrid Nunn, « "The growing Corpus of Yehud Stamp Impressions: New Finds and New Research ». Tel Aviv, 34/1, 2007, 120 p. », Abstracta Iranica [En ligne], Volume 30 | 2010, document 84, mis en ligne le 08 avril 2010, consulté le 02 octobre 2020. URL : http://journals.openedition.org/abstractairanica/ 37665 ; DOI : https://doi.org/10.4000/abstractairanica.37665

Ce document a été généré automatiquement le 2 octobre 2020.

Tous droits réservés 
« The growing Corpus of Yehud Stamp Impressions: New Finds and New Research ». Tel Aviv, 34/1, 2007, $120 \mathrm{p}$.

\author{
Astrid Nunn
}

Le premier fascicule de la revue Tel Aviv en 2007 est consacré aux empreintes de cachets Yehud de l'époque achéménide et paléo-hellénistique. Cette publication contient 532 exemplaires, dont 56 publiés pour la première fois. O. Lipschits et $D$. Vanderhooft relatent tout d'abord l'histoire de la publication de ces empreintes depuis les premières découvertes en 1898 (pp. 3-11). Ces deux auteurs présentent dans le chapitre suivant (pp. 12-37) une nouvelle typologie comprenant 17 groupes remontant à trois tranches chronologiques différentes. Yitzhak Magen et Benny Har-Even nous font découvrir 30 nouveaux cachets imprimés sur des jarres fouillées de 1992 à 2003 sur le site de Nebi Samwil à quelque $7 \mathrm{~km}$ au Nord Est de Jérusalem (pp. 38-58). Il est évident que ce site, dont le nom biblique est controversé, était un centre administratif d'une certaine importance. Les chapitres suivants sont consacrés aux empreintes non encore publiées de la Cité de David (pp. 59-65), de Ein Gedi (pp. 66-73), de Ramat Rahel (pp. 74-89) et Jérusalem (pp.90-91). Les autres parties de cet excellent rapport proposent des réévaluations chronologiques.

\title{
INDEX
}

Thèmes : 3.2.2. Pré-Achéménides et Achéménides 


\section{AUTEURS}

\section{ASTRID NUNN}

Université de Munich 